\title{
PENGARUH KOMPENSASI, BEBAN KERJA DAN PERSEPSI JENJANG KARIR DENGAN KEPUASAN KERJA SEBAGAI PEMEDIASI TERHADAP LOYALITAS PERAWAT (STUDI PADA RUMAH SAKIT SWASTA TIPE D DI KABUPATEN BANYUMAS)
}

\author{
Khusnul KA. Nurcahyanti, Dyah Retno Kuswandani \\ Administrasi Manajemen Rumah Sakit, Yayasan Kusuma Husada Purwokerto \\ E-mail: arumgusta@gmail.com.
}

\begin{abstract}
Loyalty is a person's attitude to maintain his job and do the job with maximum. Loyalty level's can be seen from the turnover, some things that become loyalty factoris job satisfaction, compensation, work load, and career ladder perception. This study aims to determine statistically the influence of variable compensation, workload and perception with job satisfaction as a mediator of nurse loyalty in Type D Private Hospital in Banyumas Regency. The research sampling method using propotional random sampling amounted to 40 nurses. Data collection techniques by survey by distributing questionnaires. The method of analysis used is regression analysis. From the results of this study can be concluded that job satisfaction, compensation, and career ladder perception have an effect on nurse loyalty, work load does not have an effect on loyalty, compensation and perception of career ladder influence to job satisfaction and work load does not have an effect on to nurse job satisfaction.
\end{abstract}

Keywords : compensation, workload, perception of career, satisfactio

\section{PENDAHULUAN}

Manajemen merupakan suatu proses yang membedakan-bedakan atas perencanaan, pengorganisasian, penggerakan pelaksana dan pengawasan dengan memanfaatkan baik ilmu maupun seni agar dapat menyelesaikan tujuan yang telah ditetapkan (R.Terry George, 2010). Manajemen perlu diterapkan di Rumah sakit karena merupakan organisasi dengan berbagai petugas kesehatan yang berhubungan dengan pelayanan kesehatan. Rumah sakit perlu sistem manajemen yang bersifat menyeluruh dan berkelanjutan untuk mengatur segalanya guna mencapai tujuan dari suatu organisasi.

Rumah Sakit Swasta Tipe D merupakan klasifikasi rumah sakit dengan fasilitas kesehatan paling minimal. Sehingga pendapatan yang diperoleh dari rumah sakit tersebut berbeda dengan rumah sakit klasifikasi yang lain. Sehingga minat calon pendaftaran pegawai baru rendah, mereka lebih memilih mendafatr di rumah sakit lain dengan klasifikasi yang lebih tinggi (Permenkes, 2010). Rumah sakit dinyatakan berhasil melakukan pelayanan kesehatan ketika kunjungan ulang pasien tinggi. Pemegang peran paling dominan di rumah sakit adalah $40 \%$ dipegang oleh perawat. (Depkes RI, 2008). Pelayanan kesehatan yang diberikan seorang perawat dipengaruhi oleh loyalitas perawat. Perawat yang loyal terhadap tempat kerjanya akan melakukan pelayanan kesehatan secara maksimal. Loyalitas perawat muncul ketika seorang perawat tersebut merasa kepuasan bekerja di rumah sakit tersebut (Nawawi, 2008) 
Tingkat loyalitas seorang perawat dapat dilihat dari turnover seorang perawat pada suatu rumah sakit. Yaseen A Hayajneh (2009) menyatakan bahwa tingkat turnover perawat masih tinggi yaitu 36,6\% pertahun Leodoro (2016) dalam penelitiannya menyatakan bahwa salah satu faktor yang mempengaruhi retensi seorang perawat disebabkan oleh kepuasan kerja dan tingkat stress kerja. Tarannum (2013) dalam penelitiannyan menyatakan bahwa penyebab suatu ketidakpuasan seorang perawat dipengaruhi oleh gaji yang diperoleh. Sama halnya dengan penelitian yang dilakukan oleh Agustina (2016) bahwa kompensasi serta beban kerja secara signifikan mempengaruhi loyalitas karyawan. Joyce (2017) menyatakan variabel yang berkonstribusi terhadap burnout berfariasi salah satunya iyalah faktor kelelahan karena beban kerja yang tinggi yaitu sebanyak $40 \%$. Kejadian turnover perawat disuatu rumah sakit terjadi peningkatan yaitu $15 \%$ pada tahun 2014- 2017, sehingga peneliti melakukan penelitian untuk melihat faktor yang mempengaruhi loyalitas seorang perawat di Rumah Sakit Swasta Tipe D dilihat dari kepuasan kerja, kompensasi, beban kerja perawat serta persepsi tentang jenjang karir.

\section{METODOLOGI}

Penelitian ini merupakan penelitian kuantitatif dengan pendekatan cross sectional. Tujuan dari penelitian ini adalah untuk mengetahui faktor yang berpengaruh terhadap loyalitas yaitu kepuasan kerja sebagai faktor pemediasi, kompensasi, beban kerja serta persepsi jenjang karir di Rumah Sakit Swasta Tipe D di Kabupaten Banyumas. Subyek dalam penelitian ini adalah perawat yang ada di Rumah Sakit Swasta Tipe D di Kabupaten Banyumas. Penentuan jumlah subyek menggunakan simple random sampling dan diperoleh hasil sebanyak 40 orang perawat. Pengambilan sampel disetiap rumah sakit pada penelitian ini menggunakan teknik propotional random sampling. Sumber data terdiri dari data sekunder yang diperoleh dari bagian manajemen rumah sakit serta data primer yang diambil langsung dari responden melalui kuisioner. Data yang telah diperoleh dianalisis dengan menggunakan uji Regresi Linier. Jumlah sampel yang diteiti dalam penelitian ini sebanyak 40 perawat.

\section{HASIL DAN PEMBAHASAN}

\subsection{Hasil penelitian}

Karakteristik responden menunjukan bahwa umur responden terbanyak adalah $<30$ tahun dengan mayoritas berjenis kelamin perempuan. Tingkat pendidikan perawat yang dominan D III Keperawatan dengan masa kerja $<3$ tahun. Berdasarkan hasil penelitian univariate menghasilkan sebanyak $60 \%$ perawat loyal. Sebanyak 62,5\% perawat menyatakan puas dengan pekerjaannya serta 72,5\% perawat menyatakan kompensasi yang diperoleh cukup. Sedangkan sebanyak 57,5\% perawat merasa terbebani dengan pekerjaannya dan sebanyak 52,5\% persepsi mereka terhadap jenjang karir baik.

Hasil analisis multivariat menyatakan bahwa ada pengaruh kepuasan kerja yg signifikan/ bermakna terhadap loyalitas perawat dengan nilai $\mathrm{p}$ value 0004 ,erdapat pengaruh antara kompensasi terhadap loyalitas perawat dengan nilai sig 0,000 sedangkan tidak adanya pengaruh antara beban kerja dengan loyalitas perawat karena nilai sig sebesar 0,148 dan adanya pengaruh antara persepsi jenjang karir terhadap loyalitas sebesar 0,001. Untuk variabel kompensasi berdasarkan hasil uji multivariat menyatakan bahwa adanya pengaruh terhadap lepuasan kerja dengan nilai signifikan sebesar 0,000. Ttidak ada pengaruh antara beban kerja terhadap kepuasan kerja karena $\mathrm{p}$ value 
diperoleh sebesar 0,961 serta terdapat pengaruh antara persepsi jenjang karir terhadap kepuasan kerja dengan nilai sig 0,018 .

Tabel 1.Uji Multivariat Pengaruh Terhadap Loyalitas

\begin{tabular}{lccccc}
\hline \multicolumn{1}{c}{ Variabel } & B & Std.Eror & Beta & T & Sig \\
\hline Kepuasan &, 330 &, 160 & 326 & 3,112 &, 004 \\
Kompensasi &, 525 &, 116 & 479 & 4.530 &, 000 \\
Beban Kerja &, 158 &, 106 &, 159 & 1,481 &, 148 \\
Persepsi Jenjang Karir &, 394 &, 104 &, 401 & 3,768 &, 001 \\
\hline
\end{tabular}

Tabel 2.Uji Multivariat Pengaruh Terhadap Kepuasan Kerja

\begin{tabular}{lccccc}
\hline \multicolumn{1}{c}{ Variabel } & B & Std.Eror & Beta & T & Sig \\
\hline Kompensasi & $-1,718$ &, 418 &,- 536 & $-4,114$ &, 000 \\
Beban Kerja &,- 014 &, 511 &,- 006 &,- 048 &, 961 \\
Persepsi Jenjang Karir &,- 617 &, 153 &,- 316 & $-1,481$ &, 018 \\
\hline
\end{tabular}

Mayoritas perawat di Rumah Sakit Swasta Tipe D di Kabupaten Banyumas berusia < 30 tahun sebanyak $65 \%$, berjenis kelamin perempuan sebanyak $60 \%$, berpendidikan DIII Keperawatan 75\%, lama kerja $<3$ tahun sebanyak 67,5\%. Kemampuan seseorang perawat dalam berpikir kritis dalam melakukan periode asuhan keperawatan selama usia dewasa dengan banyaknya kasus dan pengalaman yang diperoleh, Potter \& Perry (2009).Menurut Erikson pada usia tersebut merupakan tahap perkembangan generativitas ide-ide, keinginan berbagi pengetahuan serta meningkatkan kompetensi (Sunaryo, 2004).

\subsection{Pembahasan}

Jenis kelamin yang mendominasi di rumah sakit adalah wanita, dimana wanita menurut Robins (2006), mempunyai peran ganda dan tanggung jawab dalam keluarga dan perawatan anak serta sebagai pencari nafkah sekunder. Graham (2005) menyatakan bahwa wanita memiliki tantangan lebih besar sehingga membentuk mereka memiliki komitmen yang tinggi. Pendidikan merupakan faktor tidak langsung yang berpengaruh terhadap kinerja. Sebahian besar perawat yang bekerja di rumah sakit swasta berpendidikan D III Keperawatan. Semakin tinggi pendidikan seseorang maka besar keinginan untuk memanfaatkan pengetahuan dan keterampilan yang dimilikinya (Siagian, 2009). Hal ini pula yang kemungkinan menjadi dasar bagi manajemen dan perawat di Rumah Sakit Swasta Tipe D di Kabupaten Banyumas untuk berkomitmen meningkatkan kualifikasi pendidikan SDM keperawatan yang ada. Semakin lama bekerja semakin banyak pengalaman sehingga produktivitas kerja meningkat. Sebagian besar perawat di rumah sakit swasta tipe $\mathrm{D}$ bekerja dengan lama kerja $<3$ tahun.

Hasil olah data pada hasil jawaban responden, ditemukan bahwa kepuasan kerja berhubungan terhadap loyalitas perawat. Ketika perawat memiliki kepuasan kerja yang tinggi, mka perawat tersebut akan menjaga komitmen di rumah sakit tersebut. Keadaan tersebut senada dengan pendapat dari oleh Wibowo (2013) menyatakan bahwa karyawan dengan kepuasan kerja yang tinggi 
menunjukan sikap positif terhadap pekerjaan yang menjadi tanggung jawabnya. Serta menurut Oflat (2016) mengemukakan dalam penelitiannya bahwa perawat puas terhadap pekerjaan mereka, maka mereka akan memiliki perasaan yang positif terhadap pekerjaan mereka. Ketika perawat merasa organisasi memperlakukan mereka dengan adil dan baik sehingga mereka akan bersikap tanggung jawab untuk tetap bekerja keras untuk rumah sakit tempat mereka bekerja.

Loyalitas karyawan ditunjukan dengan komitmen karyawan didalam perusahaan, komitmen dalam berorganisasi dapat terbentuk karena adanya beberapa faktor baik dari organisasi maupun individu sendiri (Fathiya, 1014). Sehingga dalam uji multivariate penelitian ini menunjukan bahwa adanya pengaruh kepuasan kerja terhadap loyalitas dengan nilai sig 0,004. Menurut Robbins (2006) teori hierarki kepuasan seseorang dapat dilihat ketika beberapa kebutuhan terpenuhi, dalam hal ini adalah kebutuhan secara fisiologis serta keamanan. Kebutuhan fisiologis perawat dirumah sakit dapat terpenuhi dengan melihat hasil univariate sebagian besar menyatakan kompensasi yang diterima cukup. Sedangkan kebutuhan keamanan dalam hal ini adalah hidup kedepan yaitu jenjang karir dimana sebagian perawat menyatakan persepsi jenjang karir mereka baik.

Hasil penelitian ini relevan dengan hasil penelitian Pratama (2014), Muhammad (2016), Juliani (2016) yang menyatakan bahwa kompensasi mempunyai pengaruh yang positif terhadap loyalitas. Murty (2011) menyampaikan bahwa dasar untuk mempertahankan karyawan salah satu caranya adalah dengan pemberian kompensasi. Sedangkan menurut Hasibuan (2011) kompensasi mampu memenuhi kebutuhan hidup dan mampu meningkatkan kesejahteraan hidupnya. Sehingga ketika yang mereka terima mampu memenuhi kebutuhan hidupnya mereka akan tetap bertahan.

Hasil analisis bivariat hubungan kompensasi terhadap loyalitas perawat mempunyai nilai $\mathrm{p}=$ 0,000 yang berarti terdapat hubungan yang signifikan antara kompensasi dengan loyalitas perawat. Dessler (2015) menyatakan bahwa kompensasi meliputu semua bentuk bayaran yang diberikan kepada karyawan. Tujuan dari pemebrian kompensasi adalah untuk mempertahankan karyawan, bentuk keadilan serta penghargaan bagi karyawan (Handoko, 2008). Rahmadana (2015) menyatakan apabila kompensasi yang dikelola secara baik dan benar,tingkat loyalitas karyawan terhadap perusahaan akan meningkat, karena apabila loyalitas menurun maka akan merugikan perusahaan. Penelitian tersebut diidentifikasikan oleh Dwija dkk (1014) mengatakan bahwa untuk mengetahui loyalitas dari karyawan untuk perusahaan dapat dilihat dari kompensasi yang diberikan perusahaan terhadap karyawan. Penelitian tersebut senada dengan penelitian yang dilakukan oleh Hassan (2013) yang menghasilkan adanya korelasi antara kompensasi terhadap loyalitas.

Kompensasi merupakan suatu penghargaan yang diberiikan kepada karyawan sebagai balai jasa atau konstribusi yang karyawan berikan kepada perusahaan (Panggabean, 2011). Sehingga kompensasi merupakan faktor penting yang perlu dipertahatikan rumah sakit guna mempertahankan karyawannya. Dalam analisis multivariate diperoleh hasil bahwasanya kompensasi memiliki pengaruh terhadap loyalitas hal tersebut dapat diketahui dari hasil nilai sig 0,000 sehingga dinyatakan adanya pengaruh kompensasi terhadap loyalitas. Muhammad (2016), menunjukan bahwa kompensasi berpengaruh positif terhadap kinerja karyawan yang menimbulkan kepuasan kerja sehingga loyalitas akan meningkat. Hal ini senada dengan penelitian yang dilakukan oleh Juliani (2015) menyatakan bahwa kompensasi memiliki pengaruh positif terhadap loyalitas karyawan.

Hasil analisis bivariat hubungan beban kerja terhadap loyalitas perawat mempunyai nilai $\mathrm{p}=$ 0,097 yang artinya tidak terdapat hubungan yang signifikan antara beban kerja dengan loyalitas kerja perawat di Rumah Sakit Swasta Tipe D di Kabupaten Banyumas. Penerapan beban kerja mampu membuat karyawan mengeluarkan seluruh potensi yang dimiliki. Tarwaka (2010) menyatakan bahwa beban kerja dedifinisikan sebagaisebagai suatu perbedaan antara kapasitas atau 
kemampuan pekerja dengan tuntutan pekerjaan yang harus dihadapi. Robbins (1007) menyatakan positif negatifnya beban kerja seseorang tergantung masalah presepsi individu masing-masing. Steers dalam (Kusumo, 2006) menyatakan bahwa faktor yang menyebabkan timbulnya loyalitas meliputi karakteristik pekerjaan, berupa tantangan kerja, job stress, kesempatan berinteraksi serta kecocokan tugas. Tetapi pada penelitian ini diperoleh hasil bahwa tidak ada hubungan antara beban kerja terhadap loyalitas. Keadaan ini bisa disebabkan karena terdapat faktor lain lebih dominan yaitu terkait dengan kepuasan. Dimana tingak kepuasan perawat mencapai 62,5\%, salah satu faktor yang menyebabkan kepuasan adalah pemberian kompensasi. Ketika seorang banyak tuntutan akan pekerjaannya tetapi mendapat kompensasi yang dirasa cukup maka perawat akan merasa adil sehingga tetap menjaga loyalitas mereka. Hasil tersebut sama halnya dengan penelitian yang dilakukan oleh Beheshti (2015).

Hasil penelitian multivariate memperoleh nilai sig sebesar 0,148 sehingga dapat disimpulkan bahwa tidak ada pengaruhnya beban kerja terhadap loyalitas perawat. Penelitian ini tidak sebanding dengan penelitian yang dilakukan oleh Joyce (2017) yang menyatakan salah satunya penyebab burnout adalah faktor kelelahan. Salah satu penyebab beban kerja tidak berpengaruh terhadap loyalitas adalah adanya kompensasi yang dirasa cukup seperti penelitian yang dilakukan oleh Siboro (2012) serta Dharmawan (2010) yang menyatakan bahwa kompensasi mampu mempengaruhi secara kuat terhadap loyalitas seorang karyawan. Hal tersebut diperkuat dari hasil penelitian yang dilakukan nilai beta paling tinggi pada variabel kompensasi, sehingga kompensasi merupakan faktor paling kuat yang mempengaruhi loyalitas.

Hasil penelitian bivarian mendapatkan hasil bahwa terdapat hubungan antara persepsi jenjang karir terhadap loyalitas perawat dengan nilai sig 0,016. Ketika seorang perawat memiliki persepsi jenjang karir yang baik maka akan memiliki loyalitas kerja yang tinggi. Keadaan tersebut dibuktikan denga penelitian yang dilakukan oleh Yang (2014) yang menyatakan bahwa perkembangan karir seorang karyawan akan mengurangi tingkat turnover Weng (2010) menyatakan bahwa pertumbuhan karir mampu mempengaruhi komitmen terhadap rumah sakit. Keadaan tersbu didukung oleh Marquis san Huston (2010) yang mengungkapkan bahwa salah satu solusi untuk mencegah terjadinya pergantian karyawan adalah penerapan system jenjang karir.

Indikator persepsi jenjang karir salah satunya adalah adanya pengakuan, dimana mampu menurunkan stress pekerjaan serta meningkatkan kepuasan kerja, ketika seseorang merasa puas mereka akan segan untuk meninggalkan tempat kerja mereka (Tabak\&Koprak, 2007). Keadaan lain diperkuat dengan hasil univariat yang menyatakan bahwa tingginya tingkat persepsi jenjang karir baik. Sedangakn untuk hasil penelitian multivarian menyatakan bahwa nilai sig diperoleh sebesar 0,001 yang artinya adanya pengaruh antara persepsi jenjang karir terhadap loyalitas perawat. Persepsi dapat diartika sebagai suatu proses dimana individu mengorganisasikan dan menafsirkan kesan indra mereka agar memberi makna kepada lingkungan mereka (Robbin, 2007). Ketika seseorang kurang dukungan dalam pengembangan karir maka akan berdampak terhadap keluarnya perawat dari suatu rumah sakit. Hal tersebut senada dengan penelitian yang dilakukan oleh Carol (2015) yang menyatakan bahwa turnover merupakan masalah besar sehingga perlu adanya strategi untuk mempertahankan perawat salah satunya yaitu dengan adanya system jenjang karir. Berdasarkan analisis yang dilakukan seorang perawat yang telah matang dalam karirnya mereka tidak memiliki respon untuk meninggalkan rumah sakit tersebut Hasil tersebut relevan dengan penelitian yang dilakukan oleh Yang (2015).

Hasil penelitian bivarit antara variabel kompensasi terhadap kepuasan kerja menyatakan adanya hubungan yang signifikan.Teori hierarki kebutuhan yang diungkapkan oleh Maslow dalam 
(Robbins, 2015) setiap manusia terdapat lima kebutuhan salah satunya adalah kebutuhan fisiologis, rasa aman, social, penghargaan dan aktualisasi diri. Dengan bekerja seseorang dapat mengatasi kebutuhan lapar, haus, memiliki tempat berlindung. Ketika seseorang merasa semua kebutuhan dapat diperoleh mereka akan merasa puas dengan pekerjaan yang dilakukannya. Hasil penelitian multivariate diperoleh nilai sig 0,000 yang berarti bahwa kompensasi berpengaruh terhadap kepuasan bekerja di rumah sakit swasta tipe D. Menurut Robbins (2013) mengungkapkan bahwa kepuasan kerja seseorang merupakan sikap positif seseorang terhadap pekerjaannya. Dinilai dari imbalan yang mereka terima. Pendapat tersebut sama halnya dengan pendapat menurut Kevin (2016) yang menyatakan bahwa kompensasi berpengaruh positif terhadap kepuasan kerja. Penelitian tersebut diperkuat oleh penelitian yang dilakukan oleh Nugroho dan Kunartina (2011) yang menemukan bahwa kompensasi serta kepuasan kerja memiliki pengaruh yang signifikan.

Kompensasi memiliki peran yang penting bagi karyawan karena dengan adanya kompensasi merupakan instrument penting seorang karyawan untuk memenuhi kebutuhannya serta kompensasi merupakan bentuk kepedulian yang organisasi berikan terhadap pekerja. Hal tersebut didukung olrh penelitisn yang dilakuakn oleh Gupta (2014) bahwa uag merupaka motivator seseorang melakukan pekerjaan, kompensasi yang baik merupakan faktor kunci memuaskan karyawan. Penelitian tersebut relevan dengan yang dilakukan oleh Adeoye dan Fields (2014) yang menyimpulkan bahwa terdapat pengaruh antara kompensasi terhadap kepuasan kerja karyawan. Maguongo (2015) berpendapat bahwa kompensasi mempengaruhi kepuasan kerja sedangakan menurut Asghar (2016) menyatakan bahwa sistem reward yang diterima ada hubungan secara langsung terhadap kepuasan kerja.

Hasil analisis bivariate hubungan beban kerja terhadap kepuasan perawat mempunyai nilai $\mathrm{p}$ $=0,147$ yang artinya tidak terdapat hubungan yang signifikan antara beban kerja dengan kepuasan kerja perawat di Rumah Sakit Swasta Tipe D di Kabupaten Banyumas. Faktor penyebab ketidak puasan berasal dari kondisi luar (ekstrinsik) pekerjaan seperti gaji, kondisi kerja, jaminan pekerjaan, prosedur perusahaan, kebijakan perusahaan, mutu supervise, hubungan dengan supervisor, hubungan dengan rekan sejawat, hubungan dengan bawahan serta status. Ketika faktor tersebut tidak bagus, maka akan memunculkan ketidakpuasan. Namun jika faktor tersebut dinilai baik makan akan memotivasi secara kuat, sehingga bisa menghasilkan prestasi kerja yang baik (Bahtiar, 2010). Berdasarkan hasil penelitian, diperoleh tidak terdapat korelasi yang signifikan antara variabel beban kerja dengan kepuasan kerja, ini berarti bahwa tidak ada hubungan antara beban kerja dengan kepuasan kerja perawat. Keadaan tersebut disebabkan karena faktor lain, salah satunya adalah adanya kompensasi yang cukup serta persepsi terhadap jenjang karir yang baik. Hal tersebut diperkuat oleh pernyataan Bahtiar (2010) berpendapat bahwa kompensasi merupakan salah satu faktor menciptakan kepuasan kerja.

\section{KESIMPULAN}

Hasil penelitian ini berhasil membuktikan bahwa ada beberapa faktor yang mempengaruhi loyalitas perawat yaitu kompensasi, kepuasan kerja serta persepsi jenjang karir. Selain itu, penelitian ini juga membuktikan bahwa kompensasi dan persepsi jenjang karir merupakan faktor yang mempengaruhi kepuasan kerja Penelitian ini menunjukan bahwa kepuasan kerja, kompensasi dan persepsi jenjang karir mempengaruhi loyalitas perawat. Hal ini berimplikasi agar rumah sakit memperhatikan factor- factor yang meningkatkan loyalitas perawat terhadap rumah sakit Memperhatikan beberapa factor yang memepengaruhi kepuasan kerja perawat. Pemberian kompensasi didasari dengan asas keadilan, yaitu adanya pertimbangan antara beban kerja yang 
dilakukan dengan hasil yang diperoleh Pihak rumah sakit perlu melakukan sosialisasi terkait jenjang karir dirumah sakit tersebut.

\section{Saran}

Hasil penelitian menunjukan bahwa kompensasi dan persepsi jenjang karir berpengaruh terhadap kepuasan kerja. Hal ini berimplikasi agar rumah sakit memperhatikan hal berikut: Pengelolaan jasa medis yang dapat diterima oleh semua pihak dengan ketentuan yang lebih baku dan lebih terbuka. Melakukan sosialisasi tentang permasalahan pengaturan keuangan. Pimpinan perlu memberikan kesempatan terhadap perawat untuk menjadi lebih berkembang dengan menyediakan dana untuk menjalani pengembangan profesi baik melalui pendidikan lanjut, pelatihan maupun seminar Manajemen melakukan sosialisasi terkait tata aturan tentang jenjang karir

\section{DAFTAR PUSTAKA}

Adeoye, A.O.\& Fields,Z. (2014). Compensation Management and Employee Job Satisfaction: A Case of Nigeria. Journal Social Science, Vol. 41, No.3, pp. 345-352.

Afshar, H.S dan Doosti, M.(2016). Investigating the Impact of Satisfaction/ Dissatisfaction. Iranian Journal of Languagr Teaching Research, Vol.4, No.1, pp 97-115.

Agustina,Heryati. (2016). Pengaruh Kompensasi dan Beban Kerja Terhadap Loyalitas Karyawan di Departemen Operasi PT. Pupuk Sriwidjaja Palembang.Jurnal Ecoment Global Vol.1 No.2

Altaf, A., Awam,M. (2011). Moderating Affect of Workplace Spiritualityon The Relation of The Job Overload and Job Satisfaction. Journal of Bussines Ethic. 104(1), pp 93-94.

Astuti, Diah Puji.(2014) Pengaruh Kompensasi Terhadap Retensi Karyawan Melalui Kepuasan Kerjadan Komitmen Afektif pada Beberapa Rumah Sakit di DKI Jakarta.Jurnal Manajemen dan Pemasaran Jasa

As'ad, M. (2008). Psikologi industri. Edisi 4. Cetakan kesepuluh. Yogyakarta: Liberti.

Brunetto, YO \& Teo, S. (2013) Retention, Burnout, and The Future Nursing. Journal of Advanced Nursing Vol.69, No.12

Carayon, P.,\& Gurses, A.P.(2008). Nursing Workload and Patient Safety: A Human Factors Engineering Perspectives.Patient Safety and Quality : An Evidence-based Handbook For Nurses, 1-14

Debra CHairr, Helen Salisbury, Mark Johannsson. (2014). Nurse Staffing and the Relationshipto Job Satisfaction and Retention.Applied Nursing Reserch./www.elsevier.com/locate/apnr.

Dhanis,Rama,D.(2010). Pengaruh Stres Kerja, Beban Kerja terhadap Kepuasan Kerja (Studi pasa Medical Representatif Kota Kudus). Jurnal Pasikology Universitai Murai Kudus Vol.1,No.1

Gibson, J.L., J.M. Ivancevich \& J. H. Donnelly. (2000). Organizations: Behavior,Structure and Processes.McGraw-Hill Companies, Inc., New York.

Gillies, D.A. (1994). Nursing management a system approach. (3thed). Philadelphia: W.B. Sounders Company. 
(1996). Manajemen keperawatan suatu pendekatan sistem.(Edisi kedua) Philadelphia: W.B. Sounders Company. Terjemahan.

Gupta, Manisha. (2014). Employees Satisfaction Towards Monetary Compensation Practices. Global Journal of Finance and Management, Vol.6 No. 8, pp. 757-764.

Hanan Al-Ahmadi. (2008). Factor Affecting Performance of Hospital Nurses in Riyadh Region, Saudia Arabia. International Journal of Contemporary Hospitality Management, Vol. 22 Iss 5 pp. 693-717

Hariyono,W.,Dyah,S.,dan Yanuk,W.(2009). Hubungan Antara Beban Kerja, Stress Kerja dan Tingkat Konflik dengan Kelelahan Kerja Perawat di Rumah Sakit Islam Yogyakarta PDHI Kota Yogyakarta.Jurna KesMas UAD, Vol.3 No.3

Hasibuan, M.S.P. 1996. Organisasi dan Motivasi: Dasar-Dasar Peningkatan Produktivitas. Jakarta: Bumi Aksara

Hasibuan, M.SP. 2012. Manajemen Sumber Daya Manusia. Edisi Revisi Penerbit Bumi Aksara. Jakarta

Huber,D. (2000). Leadership and nursing care management. ( 2 nd ed). Philadelphia: W.B. Sounders Company.

Hurriyanti, Ratih (2005), Brauran Pemasaran dan Loyalitas Pelanggan, Penerbit CV Alfabeta, Bandung

Ilyas Y, (2011). Perencanaan SDM rumah sakit, teori, metoda dan formula. Cetakan ketiga. Penerbit FKM UI. Depok.

(2002). Kinerja, teori, penilaian, dan penelitian. Depok : Pusat Kajian Ekonomi Kesehatan FKM UI

(2004). Perencanaan SDM rumah sakit teori, metode dan formula. (Edisirevisi). Jawa Barat: FKM-U

Joyce L.Neumann,Lih-Wen Mau (2017). Burnout, Moral Distress, Work-Life Balance and Career Satisfaction among Hematopoietic Cell Transplantation Professionals. Applied Nursing Reserch./www.elsevier.com/locate/apnr.

Juliani, Retno Djohar. 2015. Pengaruh Kompensasi Terhadap Loyalitas Karyawan. Jurnal Ekonomi dan Bisnis Universitas Pandanaran Semarang Vol. No.2

Kementrian Kesehatan Republik Indonesia. Keputusan menteri kesehatan Republik Indonsia Nomor 51/MENKES/SK/I/2009 tentang Tenaga Kefarmasian.

Kementrian Pemberdayagunaan Aparatur Negara. Keputusan Menteri Pemberdayaan Aparatur Negara nomor: KEP/75/M.PAN/7/2004 tentang pedoman perhitungan kebutuhan pegawai berdasarkan beban kerja dalam rangka penyusunan formasi pegawai negeri sipil. Jakarta.

Kevin F.S Tambengi, Christoffel Kojo, Farlane S. Rumokoy. (2016). Pengaruh Kompensasi, Beban Kerja, dan Pengembangan Karir Terhadap Kepuasan Kerja Karyawan PT Telekomunikasi Indonesia Tbk. Jurnal Emba Vo.4 No.4 
Leodoro J.Labrague, Donna Gloe. (2017). Factor Influencing Turnover Intention Among Registered Nurse in Samar Philippines. Applied Nursing Reserch./www.elsevier.com/locate/apnr.

Lukman. (2007). Pengaruh Kepemmpinan, Kemampuan, dan Kompensasi terhadap Kinerja Perawat di RS Kusta Sungai Kundur Palembang. Majalah Kesehatan Masyarakat Depkes No. 75. Tahun XXXIX/2007 hal.14-2

Marliani, Rosleny. (2015). Psikologi Industri \& Organisasi. Bandung : Pustaka Setia.

Marquis, B.L. \& Huston, C., J. ( 2010). Kepemimpinan dan manajemen keperawatan: teori \& aplikasi, ed 4, alih Bahasa, Widyawati dkk, Editor edisi bahasa Indonesia Egi komara yuda dkk, Jakarta: EGC

Menlo Park, Calif: Addison-Wesley.Robbins, P.S. (2006). Perilaku organisasi. Edisi Bahasa Indonesia, edisi 10.Jakarta: PT. Indeks

Muguongo, M.M, Muguna A.T.,Murithi D.K. (2015). Effect of Compensation on Job Satisfaction Among Secondary School Teacher in Maara Sub-Country of Tharaka Nithi Country, Kenya, Vol 3 No. 6,pp 47-59.

Murty Windy Aprilia, Hundiwinarsih Gunasti. (2012). Pengaruh Kompensasi, Motivasi, dan Komitmen Organisasi terhadap Kinerja Karyawan bagian Akutansi (Studi Kasus pada Perusahaan Manufacture di Surabaya). Jurnal The Indonesia Accounting Review, 2(2),pp:215-228.

Nair,S.Shiny.(2008). Employee Retention.http://www.articlesbase.com/human-resourcesarticles/employee-retention-995426.html.

Nawawi, H.H, (2003), Perencanaan SDM untuk Organisasi Profit yang Kompetitif. Gadjah Mada University Press. Yogyakarta , (2008), Sumber Daya Manusia. Gadjah Mada University Press. Yogyakarta

Nitisemito, A. 2000. Manajemen Personalia. Jakarta: Ghalia Indonesia

Nugroho, Kunartinah. (2012). Analisis Pengaruh Kompensasi dan Pengembangan Karir terhadap Kepuasan Kerja dengan Mediasi Motivasi Kerja (Studi pada PNS di Sekertariat Daerah Kabupaten Pekalongan). Jurnal Bisnis dan Ekonomi.

Panggabean, M.S. (2004). Manajemen sumber daya manusia.Jakarta: Ghalia Indonesia

Peraturan Menteri Kesehatan Republik Indonesia Nomor 56 Tahun 2014 tentang Klasifikasi Perizinan Rumah Sakit.

Pratama, Adhitia, at al. 2015. Pengaruh Kompensasi, Lingkungan Kerja dan Beban Kerja Terhadap Loyalitas Karyawan Melalui Kepuasan Kerja (Studi Kasus pada Karyawan PT Kawasan Berikat Nusantara Persero Jakarta). Jurnal Ilmu Administrasi Bisnis, Vol. 4 No. 1.

Rachmawati, Ike K., (2008), Manajemen Sumber Daya Manusia, Penerbit ANDI, Yogyakarta.

Rehman, Irum dkk. (2012). The Impact Of Job Stress on Employee Job Satisfaction: A Study on Private College of Pakistan. Journal of BusinessStudies Quartely. 3(3), pp. 50-56. 
Republik Indonsia Nomor 81/MENKES/SK/I/2004 tentang pedoman penyusunan perencanaan sumber daya manusia kesehatan di tingkat propinsi, kabupaten/kota serta rumah sakit. Jakarta

Republik Indonsia Nomor 1027/MENKES/SK/I/2004 tentang Standar Pelayanan Kefarmasian Robbins, P.S. (2006). Perilaku organisasi. Edisi Bahasa Indonesia, edisi 10. Jakarta: PT. Indeks

Robbins, S. P. (2003). Organizational Behavior. Tenth Edition. Prentice Hall, Inc.,New Jersey.

Robbins, S. P. (2001). Perilaku Organisasi.Versi bahasa Indonesia. Jakarta. Prenhallindo.

Saydam, G. 2000. Manajemen Sumber Daya Manusia (Suatu Pendekatan Mikro). Jakarta: Djambatan

Silvia DE Simone,Anna Plantana.(2017). Departement of Pedagogy,Psychology, Philosophy, University of Cagliari, Via Is Mirrionis, 1,09123 Cagliari Italy

Sitorus, R. (2006). Model praktik keperawatan profesional di rumah sakit: Penataan struktur \& proses (sistem) pemberian asuhan keperawatan di ruang rawat.Jakarta: EGC

Streers, R.M. and Porter, L.W. 1983. Motivation and Work Behavior. New York: Mc Graw-Hill Book Company.

Sugeng, Budiono. (2014). Pengaruh Spiritualitas di Tempat Kerja terhadap Turnover Intention Perawat Melalui Komitmen Organisasi di Rumah Sakit Islam Unisma Malang. JUrnal Aplikasi Manajemen (JAM) Vol.12 No.4, 2014

Suwarno. 2002. Pengaruh Kepuasan Kompensasi Dan Komitmen Karyawan Pada Organisasi Terhadap Loyalitas (Studi Kajian Karyawan PT Perkebunan Nusantara XII Di Propinsi Jawa Timur). Jember: Universitas Jember

Sulistiyani, A.T. \& Rosidah ( 2003). Manajen sumber daya manusia: konsep, teori dan pengembangan dalam konteks organisasi publik. Yogyakarta: Graha Ilmu

Tabak, N. \& Koprak, O. (2007). Relationship between how nurses resolve their conflicts with doctors, their stress and job satisfaction. Journal of Nursing Management 15, 321-331

Tarannum Jahan \& U.V. Kiran (2013) An Evaluation of Job Satisfaction of Nurses Across Working Sector. International Journal of Human and Social Science Invention Volume 2 Issue 6.

Undang-undang Republik Indonesia Nomor 44 tahun 2009 tentang Rumah Sakit

Undang-undang Republik Indonesia Nomor 36 tahun 2014 tentang Tenaga Kesehatan

Undang-undang Republik Indonesia Nomor 36 Tahun 2009 tentang Kesehatan.

Umar,Husein. (2008).Desain Penelitian Manajemen Sumber Daya Manusia.Jakarta: Salemba Empat

Yaseen A Hayajneh. (2009). Turnover Rate Among Registered Nurses in Jordania Hospital: An Explanatory Study. International Journal of Nursing Practice 2009:15:303-310

Vladica M. Veličković (2014) Organizational Commitment and Job Satisfaction Among Nurses in Serbia: A Factor Analysis Nursing Outlook (2014), doi: 10.1016/j.outlook.2014.05.003. 